This item was submitted to Loughborough's Research Repository by the author.

Items in Figshare are protected by copyright, with all rights reserved, unless otherwise indicated.

\title{
World cities in the Pacific Rim: a new global test of regional coherence
}

PLEASE CITE THE PUBLISHED VERSION

http://dx.doi.org/10.1111/1467-9493.t01-1-00071

PUBLISHER

(c) Department of Geography, National University of Singapore, and Blackwell Publishers Ltd

\section{VERSION}

AM (Accepted Manuscript)

LICENCE

CC BY-NC-ND 4.0

\section{REPOSITORY RECORD}

Taylor, Peter J., M.A. Doel, Michael Hoyler, David R.F. Walker, and Jonathan V. Beaverstock. 2019. "World Cities in the Pacific Rim: A New Global Test of Regional Coherence". figshare.

https://hdl.handle.net/2134/12766. 
This item was submitted to Loughborough's Institutional Repository (https://dspace.lboro.ac.uk/) by the author and is made available under the following Creative Commons Licence conditions.

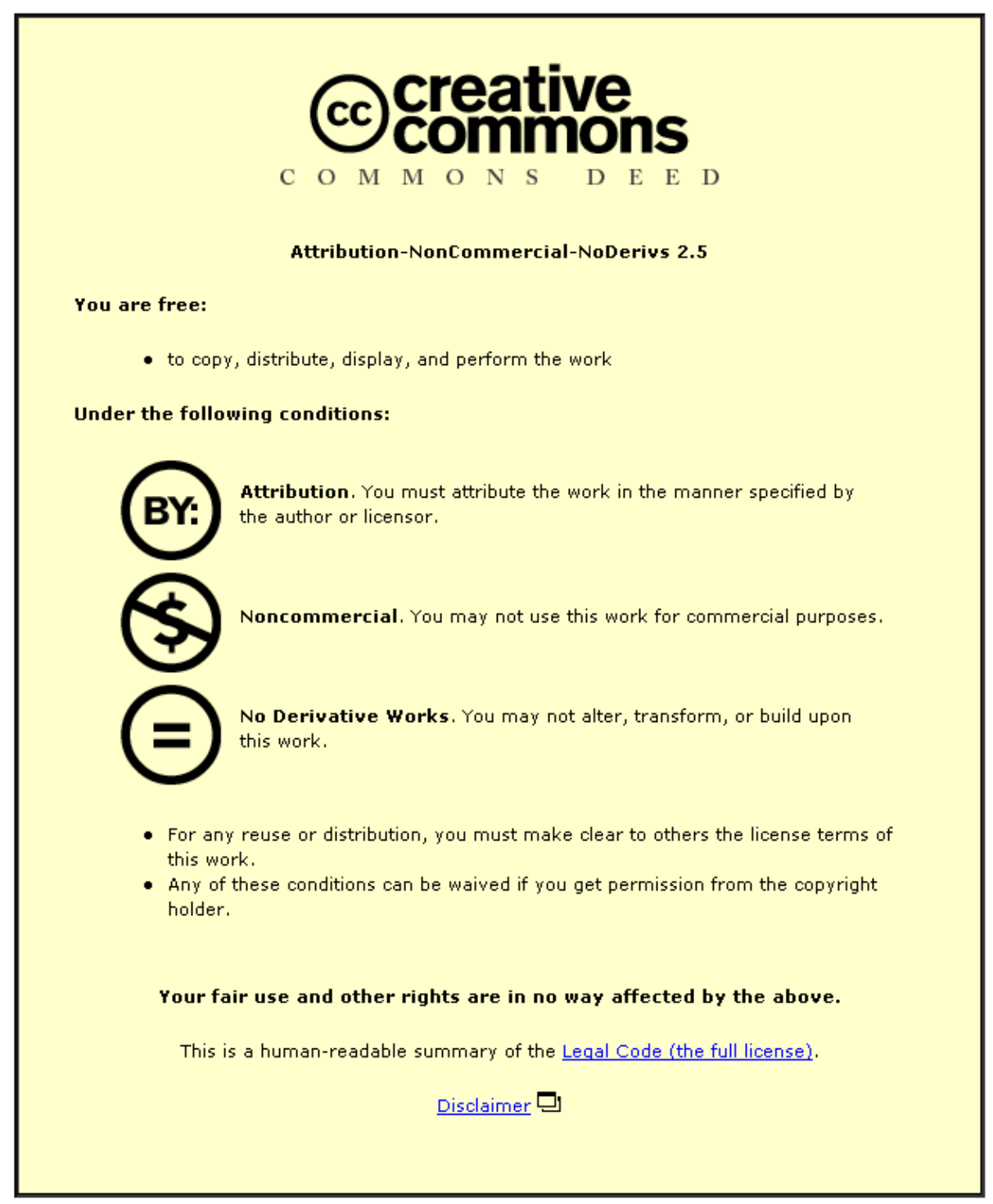

For the full text of this licence, please go to: http://creativecommons.org/licenses/by-nc-nd/2.5/ 


\title{
World cities in the Pacific Rim: a new global test of regional coherence
}

\author{
P.J. Taylor ${ }^{1}$, M.A. Doel ${ }^{1}$, M. Hoyler ${ }^{2}$, D.R.F. Walker ${ }^{1}$ and J.V. Beaverstock ${ }^{1}$ \\ ${ }^{1}$ Department of Geography \\ Loughborough University, UK \\ ${ }^{2}$ Geographisches Institut \\ Universität Heidelberg, Germany
}

\begin{abstract}
A new evaluation of the Pacific Rim concept is presented. The originality of this test for regional coherence is to be found in the basic units being analysed: cities instead of states. Based on a theoretical framework that identifies world city and world city network formation in terms of the office networks of advanced producer service firms, we use a principal components analysis to analyse a data set of 28 Pacific Rim cities and 46 global service firms. This identifies five main groupings of cities in terms of similar mixes of corporate service firms: a western Rim group; a group of 'old Commonwealth' cities; a market communist group of cities; Tokyo as a global city; and US cities as a specific separate group. These results confirm the numerous earlier studies that were sceptical of the existence of a coherent Pacific Rim region. However, the particular approach adopted here allows us to identify the Pacific Rim generically as a particularly pernicious construct. We conclude that the Pacific Rim is a geographical chaotic conception.
\end{abstract}




\section{Introduction}

'There has already been far too much speculation about the twenty-first century being the Pacific Century' (Segal, 1990: 385)

'Pacific Rim was a discourse in search of the research funds to prove the thing itself existed ... (it) is neither a self-contained region nor a community but just a rim' (Cumings, 1994: 402, 405)

As associated geo-historical constructs, the Pacific's Century and Rim are unique. They generated a consensus that they were over before they began (cf. Segal, 1990; Dirlik, 1992, 1993; Cumings, 1994; Current History, 1994; Krugman, 1994; Cook et al., 1996; Berger and Borer, 1997). There were good reasons for the widespread critique, indeed cynicism, towards these constructs which emanates from their shared providence. Triggered by the fact that the volume of trade across the Pacific overtook trans-Atlantic trade in 1983 (Daly and Logan, 1989: 2), a particular geopolitical discourse emerged in the context of concern for the relative decline of the US. The rise of first, Japan and then the four Asian 'tigers' seemed to presage a geo-economic shift towards East Asia in the world economy (Berger and Hsiao, 1988; Wade, 1990; Haggard, 1990; Appelbaum and Henderson, 1992; Leipziger and Thomas, 1993; World Bank, 1993a, 1993b; Naisbitt, 1996; Fischer, 1997; Walton, 1997). Extrapolation of growth rates pointed clearly to the world economy in the next century no longer being dominated by either Europe or the US. For the latter, there was a simple rhetorical means of keeping up with the Asians: by designating the next century 'Pacific' rather than 'Asian' the US would remain part of the centre of the world economy, courtesy of its west coast (Daly and Logan, 1989; Borthwick, 1992; Dirlik, 1992, 1993). Hence the regional construct - Pacific Rim was the necessary geographical complement to the Pacific Century.

Future time constructs are less vulnerable to criticisms than spatial constructs because while we cannot know the future, geographical investigation can interrogate the coherence of regional propositions. Thus, whereas the economic travails in East Asia in the 1990s may have made a dent in the idea of a new Pacific Century, it can remain a possibility. In contrast, the Pacific Rim has been empirically evaluated and found wanting. ${ }^{1}$ For instance, Segal (1990: 377) has concluded that no one should believe in 'a coherent Pacific region' because '(t)here is no important cultural, ideological, political, or even military sense in which it is 
particularly useful to talk of "the Pacific". No wonder such 'talk' has been denigrated as 'Rimspeak' (Cumings, 1994: 402). While this reaction is understandable, it is, nevertheless, not quite as straightforward as such dismissals suggest. All regions are constituted through their own times - they are always historical regions (Taylor, 1991) - and the 'Pacific Century-Rim' is an exemplary case of this 'time-space' theory of regions. Hence, the question is not whether the Pacific Rim is a coherent region now, but whether it is becoming such a region for its presumed time. Certainly, the dawning of the new century makes it particularly apt to reopen this matter to fresh empirical scrutiny.

Our reason for looking again at the Pacific Rim is not, of course, simply time dependent. Rather, we are illustrating a new way of considering such regional questions under conditions of contemporary globalization. Both the origins of the Pacific Rim construct and the testing of its veracity have been state-centric in nature. The Pacific Rim is envisaged as existing or not existing in a world mosaic of states where regions are defined as combinations of states. One of the effects of this state predilection is that the boundaries of the Pacific Rim as a region are very unsatisfactory since it is made up of countries that encompass large "nonPacific' areas (cf. China, Canada, USA, Mexico, and Australia). This way of geographical thinking is to work ideas through a 'space of places'. An alternative approach has been provided by Castells (1996) where his emerging network society is constituted as a 'space of flows'. Among the myriad of types of flows in this new space, world cities as 'nodal centres of the new global economy' (Castells, 1993: 250) act as a critical organising network. We follow Castells' lead here: state-mosaic thinking is replaced by a city-nodal approach. However, while Castells and others have provided plausible descriptions and concepts for this emerging space of flows, we have developed an empirical and quantitative specification of the world city network (Taylor and Hoyler, 2000; Taylor and Walker, forthcoming; Taylor, forthcoming). Given the initial stimulus for this 'Pacific thinking' was the 1983 overtaking of Atlantic trade volume, it would seem to be entirely appropriate to evaluate the Pacific Rim within a space of flows framework.

\section{A world-city network perspective}

The most obvious advantage of beginning with cities rather than states is in allowing a tighter geographical specification of the Pacific Rim (Los Angeles but not Chicago, Shanghai but not Chongqing, etc.). But the key gain is the new theoretical framework for examining relations 
between cities that our perspective provides. In this we differ from previous research on Pacific Rim cities where the empirical analysis has been largely about ranking cities by population size and change (Douglass, 1989; Lo and Yeung, 1996; Yeung and Lo, 1998). At about the same time that the concept of the Pacific Rim was being invented, John Friedmann (1986; Friedmann and Wolff, 1982) was developing his 'world city hypothesis' that linked worldwide urban development to the new international division of labour (Fröbel et al., 1980). World cities were the 'command and control centres' of the new world economy being developed by multinational corporations. Friedmann's world city hierarchy encompassed cities from around the Pacific Ocean, viewed as a part of a global pattern: at the top of Friedmann's (1986) original hierarchy were Tokyo and Los Angeles among the 'core/primary' cities, followed by Singapore as a 'semi-periphery/primary' city, and five other Pacific cities designated 'semi-periphery/secondary'. This approach was consolidated by Saskia Sassen's $(1991,1994)$ identification of the global city with particular reference to London, New York and Tokyo. With her work, world cities have been intrinsically linked to the form and content of contemporary globalization.

Sassen has provided a more precise definition of world/global cities than was offered in Friedmann's original identification. Whereas the latter treated multinational corporations in general, Sassen focuses upon those providing corporate services. She argues that the production of advanced producer services (such as financial instruments and interjurisdictional law) constitutes a cutting edge of the contemporary global economy. Furthermore, this production can only be successful in 'special places' where concentrations of specialised knowledge intersect with flows of the latest information. World cities are these special places; they are global centres servicing capital to enable it to operate 'seamlessly' across the world.

In our work at the GaWC (Globalization and World Cities Study Group and Network) based in Loughborough University, Sassen's approach has been extended to define world city network formation (Taylor, forthcoming). It follows from Sassen's argument that it is corporate service firms which specify the world city network by their office location strategies. Any world city is the creation of the service firms located there, and its position in the world city network depends upon those firms' particular patterns of offices across other world cities. In this specification, the world city network is, therefore, the amalgam of the office networks of global service firms. There are, of course, other important relations 
between cities that contribute to their 'world-cityness' and impinge on regional coherence. But we have found that this particular specification provides an efficient and very fruitful approach to these questions (Taylor and Hoyler, 2000; Taylor and Walker, forthcoming). In short, our approach builds upon the first formal specification of the world city network. Its very tight definition is a necessary first step towards empirical investigation of this network.

\section{World city data and analysis}

We originally collected data for 69 producer service firms (in accountancy, advertising, banking/finance and law) for 263 cities across the world covering a period straddling 1997 and 1998. From this material, we identified 55 world cities and another 68 cities showing evidence of world city formation (Beaverstock et al., 1999a). Of the 55 world cities, 11 are Pacific Rim cities and there are a further 11 cities that were found to have some evidence of world city formation (Table 1). These are the 28 cities in our analysis below. In a related study, we have identified 46 'global service firms' defined as having offices in at least 15 different cities (Taylor and Walker, forthcoming). They are listed in Appendix A. For each of these 46 firms, we have a measure, from 0 to 3, of the level of service it provides in each of the 28 cities. $^{2}$ The end result is a 28 (cities) x 46 (firms) data matrix made up of 1,288 pieces of information.

To make sense of such a large amount of information requires application of techniques that reduce the data to a few common patterns. This is what the factor analytic family of multivariate statistics does. Here we employ the most basic of this group - principal components analysis. This technique is based upon correlations. The data matrix is converted into a $28 \times 28$ correlation matrix. In this matrix, each city is correlated with each other city. These correlations measure the degree of similarity between two cities' mix of corporate services: two cities sharing many of the same firms will correlate high and positive, whereas pairs of cities with very little overlap in firms will correlate high and negative. What the principal components analysis does is to use these correlations to identify principal components that abstract distinct patterns of corporate service mixes that recur across cities. (For specific details of this methodology, see Taylor and Hoyler, 2000; Taylor and Walker, forthcoming). ${ }^{3}$ The particular corporate mix of each city can then be compared to these components as new correlations. Instead of the original city-city comparisons, these are citycomponent comparisons that are called 'loadings'. In this way cities are found to 'load' high 
on some components and low on others. The high loadings are used both to allocate cities to components and then to interpret and label the components. The latter procedure produces a typology of cities based upon similar corporate mixes as identified in terms of components. Such an analysis produces four important outputs that we will use: (i) the percentage of original total variance in the data accounted for by the components collectively; (ii) the percentage of 'explained' variance accounted for by each component individually; (iii) the heart of the analysis that is the table of loadings relating cities to components; and (iv) the table of component scores that relates the firms to the components. This enables us to specify the distinguishing features of the service mix associated with a particular group of cities.

As previously described, we use this method of analysis to identify groups of cities that provide similar mixes of corporate services. Returning to our specification of the world city network, these groups represent clusters of nodes in the network, cities that are located on many of the same office networks of firms. Hence, the groupings of cities can be interpreted functionally. If we make the plausible assumption that offices belonging to the same firm will communicate more than offices belonging to different firms, it follows that evidence of two cities with many offices in the same firms' office networks will be a surrogate indicator of high levels of inter-city communications between the cities. In this way the similarities we have analysed may be interpreted in terms of relations between cities: a pair of cities sharing few firms indicates less inter-city flows of business information and knowledge, compared to a pair of cities with a large overlap in the firms located within them. Thus, groups of cities derived from a principal components analysis can be viewed, tentatively, as sub-networks within the larger world city network. Accordingly, the methodology used here is particularly suited to determining the coherence or otherwise of the Pacific Rim as viewed through its leading cities operating in a world-wide space of flows.

\section{Testing the regional coherence of the Pacific Rim}

We use principal components analysis to test for the existence of a coherent Pacific Rim macro-region in terms of inter-city relations. We refer to this as a 'global test' because our data is based upon firms with worldwide patterns of offices. We are therefore exploring regional coherence within the larger global economy. 
In this principal components analysis, regional coherence can be represented in one of two ways. The first and simplest depiction of coherence would be if there was one dominant component that accounted for nearly all the original variance. This was the original way this type of technique was used - looking for the 'general factor' in a set of data (Taylor, 1981). Were such a component to be found, it would indicate very similar mixes of corporate services across the whole set of cities, thus suggesting a coherent Pacific Rim sub-network of cities. We know from our previous analysis at the world scale (Taylor and Walker, forthcoming) that such a result is highly unlikely. The second outcome that may suggest a coherent region would be for the cities to be grouped by size or importance, but for each group to straddle continents and be represented in both east and west rims. This would imply some sort of common hierarchy of service provision across the Pacific, thus suggesting a systemic regional coherence.

Neither outcome was to be found with the present data matrix. Rather the principal components analysis generated five components that between them account for 74.2 per cent of the original variance in the data. This is a good parsimonious statistical result and the substantive findings are equally impressive. City loadings are displayed in Table 2 and component scores of firms in Table 3. The latter shows relative surplus or dearth of a service by firms for a given component mix. In addition, the five components are easily interpretable in terms of the geographies of the city groupings (Figure 1).

Component I brings together most of the Asian cities in the data with Sydney and Melbourne and is therefore labelled Western Rim Cities. With 30.6 per cent of the explained variance within this component, 12 cities are recorded in Table 2 and on Figure 1. Table 3 shows which firms score high or low. The main surplus here is the presence of Baker and McKenzie, the world's largest law firm, which is reciprocated by the dearth of selected other American law firms. There is also a noticeable surplus among some banks. The presence of the two Australian world cities here creates a component that is the closest we get to producing a coherent 'rim' component.

However, this largest component is by no means a comprehensive grouping of cities of the western rim. The remaining Australian cities group with New Zealand and Canadian cities to constitute Component II, which we call Old Commonwealth Cities. Accounting for 25.7 per cent of the explained variance, all five accountancy firms in our data exhibit surpluses in the 
scores along with selected advertising companies. This component obviously shows a British imperial legacy. Sydney and Melbourne do load on the component in Table 2, but lower than for component I.

Accounting for 23.2 per cent of the explained variance, Component III is the most interesting component. Its top four cities are from China and Vietnam and so we can label the component Market Communism Cities. Presumably, these cities involve very special circumstances in terms of relations with the party states that create a specific mix of service firms. Banks are well represented in the scores for surpluses along with the Japanese (Osaka) advertising firm - Dentsu. Baker and McKenzie is conspicuously in deficit within this group of cities.

Although to be found loading low on Component I, Asia's leading world city - Tokyo - is picked out by this analysis as distinctive enough to have what is largely its own component. We call Component $\mathrm{V}^{4}$, which accounts for 10.8 per cent of the explained variance, Global City following Sassen (1991). This finding is entirely in keeping with our previous global analysis that linked Tokyo to other international financial centres, notably Zurich and Frankfurt, rather than other Asian cities (Taylor and Walker, forthcoming: Table 2). Predictably, the scores show a surplus for firms in accountancy and banking, and a relative dearth in advertising.

The smallest component, accounting for 9.7 per cent of the explained variance, is Component IV that defines the most distinctive grouping. It includes all and only US cities in our data. We label this Pacific US Cities. The scores show that this service mix is marked by a surplus of North American law firms plus accountancy firms, and with a dearth of some advertising firms and banks. Although Los Angeles developed in the 1980s as the 'gateway' between the US and the Pacific Rim (Ong and Blumenberg, 1998: 315), this is especially reflected in immigration patterns (Soja, 1998: 442), but is not to be found in the city's corporate service mix. From the latter perspective, there is no evidence in our analysis that Los Angeles is becoming a leading Pacific world city; rather it appears as specifically US in nature.

Notice that the Latin American cities do not feature prominently in this analysis. The fact that they load weakly across all components (except for the US one where they do not feature at all) is a particular indictment of the geographically comprehensive implications of the 
concept of Pacific Rim. Quite simply, the consistently low loadings show that Latin American cities do not really fit anywhere in this analysis. Of course, despite their geographical location, the Pacific Rim concept was never really about their region in any case.

Finally, we can note that this analysis provides clear support for the scepticism of the critics of the Pacific Rim concept who we cited in our Introduction. Our contribution has been to present a detailed and rigorous empirical evaluation from a different perspective, both globaland city-oriented. There are two particular ironies in our results. First, although the debate on the Pacific Rim dates from the 1980s, the only example of a strong trans-Pacific grouping of cities (courtesy of Vancouver) has a much longer pedigree - Britain's imperial legacy of the old Commonwealth. Second, although the US is in many ways the 'author' of the Pacific Rim (Borthwick, 1992), its cities are the least related to other Pacific Rim cities. In other words, they are the most nationally introverted in terms of corporate service provision. Overall, our results show a series of largely separate groupings of cities around the Pacific, each with its own specific corporate service mix.

\section{Conclusion: the Pacific Rim as a geographical chaotic conception}

At its simplest level, this study has confirmed earlier scepticism of the concept of a Pacific Rim. Certainly, we can say that as we enter the 21 st century, there is little empirical indication to suggest the emergence of a Pacific Rim region to complement a possible Pacific Century. However, by introducing a city-nodal approach, we have taken the evaluation a stage further by breaking away from traditional state-mosaic description and analysis. This has provided a necessary theoretical framework in terms of world city and world city network formation. This use of the office networks of firms to specify relations between cities allows us to provide a generic geographical interpretation of the Pacific Rim.

A chaotic conception is an arbitrary abstraction from a wider range of relations that define a system (Sayer, 1992). It contrasts with rational conceptions that are constituted by meaningful relations within the larger whole. Thus, a chaotic conception combines together relatively unrelated parts while also dividing highly connected parts. Ideally, as a spatial concept, geographical regions should be rational conceptions that define part of a whole in terms of its interrelations. Much of the effort in defining regions focuses upon rigorous depiction of 
spatial boundaries. In contrast, a geographical chaotic conception is produced when relatively unrelated areas are arbitrarily combined and/or when similar or related areas are arbitrarily divided. It is important to appreciate the existence of geographical chaotic conceptions because they define not simply 'poorly specified regions', but 'anti-regions' - spatial categories that confuse rather than elucidate. The Pacific Rim is just such a space.

\section{Acknowledgements}

We acknowledge the support of the ESRC for this research: the data derive from project R000222050 and the ideas for the application from project R000222693.

\section{Notes}

1. The main exception is in terms of inter-governmental co-operation (Park, 1997; van Grunsven et al., 1997) that is best represented by APEC (Asian Pacific Economic Cooperation). However, the difficulties of coordinating inter-government policy should not be underestimated (Frankel and Kahler, 1993; Cook et al., 1996, 1998).

2. The original data contained different types and amounts of information on firms' offices. To make comparisons possible, this variation was converted into a simple ordinal scale, indicating a major office (3), medium size office (2), a low or simple office presence in a city (1), and absence from a city (0). For specific details, see Beaverstock et al. (1999b).

3. To make this paper self-standing, we should note that the principal components analysis reported here is Q-mode and uses a varimax orthogonal rotation. For deciding on the number of components to be rotated, a threshold of 0.7 was used: we rotated the maximum number of components where all had at least one loading over 0.7 . For discussion and justification of these decisions, see Taylor and Walker (forthcoming). These decisions are based upon our experience in working with this and other data sets. The idea is to obtain the most clearly interpretable components from a data matrix. Of course, as with all factor analytic techniques, input decisions affect the findings and different results will be produced with different decision inputs. For example, if we chose an oblique rotation, the outcome would obviously be quite different. If any reader wants to experiment with our data using different 
assumptions, the data matrix is available on the GaWC website: http://www.lboro.ac.uk/departments/gy/research/gawc.html.

4. We have presented the components in order of their statistical importance after rotation which does not correspond to the initial order of extraction from the data. Hence Component $\mathrm{V}$ is more important than Component IV in these results.

\section{References}

Appelbaum, R.P. \& Henderson, J. (eds.) (1992) States and Development in the Asian Pacific

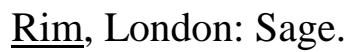

Beaverstock, J.V., Smith, R.G. \& Taylor, P.J. (1999a) 'A roster of world cities', Cities, 16, 445-458.

Beaverstock, J.V., Smith, R.G. \& Taylor, P.J. (1999b) 'The global capacity of a world city: a relational study of London', GaWC $\quad$ Research $\quad$ Bulletin $\quad$ No. 7 (http://www.lboro.ac.uk/departments/gy/research/gawc/rb/rb7.html)

Berger, M.T. \& Borer, D.A. (eds.) (1997) The Rise of East Asia: Critical Visions of the Pacific Century, London: Routledge.

Berger, P.L. \& Hsiao, H.-H.M. (eds) (1988) In Search of an East Asian Development Model, New Brunswick: Transaction Books.

Borthwick, M. (1992) The Pacific Century, Boulder, CO: Westview Press.

Castells, M. (1993) 'European cities, the informational society, and the global economy' Tijdschrift voor Economische en Sociale Geografie, 84, 247-257.

Castells, M. (1996) The Rise of the Network Society, Oxford: Blackwell.

Cook, I.G., Doel, M.A. \& Li, R. (eds.) (1996) Fragmented Asia: Regional Integration and National Disintegration in Pacific Asia, Aldershot: Avebury. 
Cook, I.G., Doel, M.A., Li, R.Y.F. \& Wang, Y. (eds.) (1998) Dynamic Asia: Business, Trade and Economic Development in Pacific Asia, Aldershot: Avebury.

Cumings, B. (1994) 'What is a Pacific Century and how will we know when it begins?', Current History, 93(587), 401-406.

Current History, 1994, theme issue on 'The Pacific Century?', Current History, 93(587), 401439.

Daly, M.T. \& Logan, M.I. (1989) The Brittle Rim: Finance, Business and the Pacific Region, London: Penguin.

Dirlik, A. (1992) 'The Asia-Pacific idea: reality and representation in the invention of a regional structure', Journal of World History, 3, 55-79.

Dirlik, A. (ed.) (1993) What is in a Rim? Critical Perspectives on the Pacific Region Idea, Boulder, CO: Westview Press.

Douglass, M. (1989) 'The future of cities in the Pacific Rim', in M.P. Smith (ed.), Pacific Rim Cities in the World Economy, New Brunswick, NJ: Transaction, 6-67.

Fischer, S. (1997) 'Lessons from East Asia and the Pacific Rim', Brookings Papers on Economic Activity, 2, 345-350.

Frankel, J.A. \& Kahler, M. (eds.) (1993) Regionalism and Rivalry: Japan and the United States in Pacific Asia, Chicago: University of Chicago Press.

Friedmann, J. (1986) 'The world city hypothesis', Development and Change, 17, 69-83.

Friedmann, J. \& Wolff, G. (1982) 'World city formation: an agenda for research and action', International Journal of Urban and Regional Research, 6, 309-344. 
Fröbel, F., Heinrichs, J. \& Kreye, O. (1980) The New International Division of Labour, Cambridge: Cambridge University Press.

Haggard, S. (1990) Pathways from the Periphery: The Politics of Growth in the Newly Industrializing Countries, Ithaca: Cornell University Press.

Krugman, P. (1994) 'The myth of Asia's miracle', Foreign Affairs, 73(6), 62-78.

Leipziger, D.M. \& Thomas, V. (1993) Lessons of East Asia: An Overview of Country Experience, Washington, DC: The World Bank.

Lo, F-C. \& Yeung, Y-M. (eds.) (1996) Emerging World Cities in Pacific Asia, Tokyo: United Nations University Press.

Naisbitt, J. (1996) Megatrends Asia: The Eight Asian Megatrends that are Changing the World, London: Nicholas Brealey.

Ong, P. \& Blumenberg, E. (1998) 'Income and racial inequality in Los Angeles', in A.J. Scott \& E.W. Soja (eds.), The City, Berkeley, CA: University of California Press, 311-335.

Park, S.O. (1997) 'Rethinking the Pacific Rim', Tijdschrift voor Economische en Sociale Geografie, 88, 425-438.

Sassen, S. (1991) The Global City, Princeton, NJ: Princeton University Press.

Sassen, S. (1994) Cities in a World Economy, London: Pine Forge Press.

Sayer, A. (1992) Method in Social Science: a Realist Approach, London: Routledge.

Segal, G. (1990) Rethinking the Pacific, Oxford: Clarendon Press.

Soja, E.W. (1998) 'Los Angeles, 1965-1992: from crisis-generated restructuring to restructuringgenerated crisis', in A.J. Scott \& E.W. Soja (eds.), The City, Berkeley, CA: University of California Press, 426-462. 
Taylor, P.J. (1981) 'Factor analysis in geographical research', in R.J. Bennett (eds.), European Progress in Spatial Analysis, London: Pion, 71-88.

Taylor, P.J. (1991) 'A theory and practice of regions: the case of Europes', Environment and Planning D: Society and Space, 9, 183-195.

Taylor, P.J. (forthcoming) 'Specification of the world city network', Geographical Analysis.

Taylor, P.J. \& Hoyler, M. (2000) 'The spatial order of European cities under conditions of contemporary globalization', Tijdschrift voor Economische en Sociale Geografie, 91, 176-189.

Taylor, P.J. \& Walker, D.R.F. (forthcoming) 'World cities: a first multivariate analysis of their service complexes', Urban Studies.

van Grunsven, L., Singh, M.S. \& Van Naerssen, T. (1997), 'The dynamics of the Asian Pacific Rim’ Tijdschrift voor Economische en Sociale Geografie, 88, 403-408.

Wade, R. (1990) Governing the Market: Economic Theory and the Role of Government in East Asian Industrialization, Princeton, NJ: Princeton University Press.

Walton, M. (1997) 'The maturation of the East Asian miracle', Finance and Development, 34(3), $7-10$.

World Bank (1993a) Sustaining Rapid Development in East Asia and the Pacific, Washington, DC: World Bank.

World Bank, (1993b) The East Asian Miracle: Economic Growth and Public Policy: Summary, Washington, DC: World Bank.

Yeung Y-M. \& Lo, F-C., 1998 'Globalization and world city formation in Pacific Asia', in F-C. Lo \& Y-M. Yeung (eds.) Globalization and the World of Large Cities, Tokyo: United Nations University Press, 132-154. 


\section{Appendix A Advanced Producer Service Firms by Sector, with abbreviations}

$\underline{\text { Accountancy }}$

AA Arthur Andersen

CL Coopers \& Lybrand

KP KPMG

EY Ernst \& Young International

PW Price Waterhouse

Advertising

AM Abbott Mead Vickers (BBDO)

DE Dentsu

DM DMB\&B (MacManus Group)

GR Grey Worldwide

TH JWT (Thompson)

LH Lowe Howard -Spink

OM Ogilvy \& Mather Direct Worldwide

PU Publicis

SS Saatchi and Saatchi

TM TMP

YR Young \& Rubicam

Banking and Finance

$\begin{array}{ll}\text { AB } & \text { ABN-AMRO } \\ \text { BA } & \text { Barclays } \\ \text { BB } & \text { BBV Group } \\ \text { BT } & \text { Banker's Trust } \\ \text { CB } & \text { Citibank } \\ \text { PA } & \text { Compagnie Financière de Paribas SA } \\ \text { CS } & \text { Credit Suisse } \\ \text { CR } & \text { Creditanstalt-Bankverein } \\ \text { DR } & \text { Dresdner Bank Group } \\ \text { MO } & \text { J P Morgan } \\ \text { HS } & \text { HSBC } \\ \text { NW } & \text { NatWest Group } \\ \text { ST } & \text { Standard Chartered Group } \\ \text { UB } & \text { UBS }\end{array}$


$\underline{\text { Law }}$

AO Allen \& Overy

BM Baker \& McKenzie

BC Bryan Cave

CC Clifford Chance

$\mathrm{CO}$ Coudert Brothers

DW Dorsey \& Whitney

FF Freshfields

GJ Graham \& James

$\mathrm{HH}$ Hogan \& Hartson

JD Jones, Day, Reavis \& Pogue

LL Leboeuf, Lamb, Greene \& MacRae

MC Miller, Canfield, Paddock, \& Stone

SK Skadden Arps

SQ Squire, Sanders \& Dempsey

WC White \& Case

WE Wilson, Elser, Moskowitz, Edelman \& Dicker

The data were collected in 1997 and 1998. Since then, there have been some mergers between firms. 


\title{
Table 1 Pacific Rim Cities
}

\author{
Alpha world cities: Tokyo, Los Angeles, Singapore, and Hong Kong \\ Beta world cities: San Francisco, Sydney, and Seoul \\ Gamma world cities: Jakarta, Melbourne, Osaka, Santiago, Taipei, Bangkok, Beijing, \\ Kuala Lumpur, Manila, and Shanghai \\ Cities with evidence of world city formation: Auckland, Brisbane, Ho Chi Minh City, \\ Lima, Seattle, Vancouver, Adelaide, Guangzhou, Hanoi, Tijuana, and Wellington
}

For details of categories and how they were created, see Beaverstock et al. (1999a) 
Table 2 Component loadings of Pacific Rim Cities (only loadings above 0.4 are shown)

\begin{tabular}{|c|c|c|c|}
\hline Loading level & $\begin{array}{l}\text { PC } 1(30.6 \%) \\
\text { Western Rim } \\
\text { Cities }\end{array}$ & $\begin{array}{l}\text { PC } 2(25.7 \%) \\
\text { Old } \\
\text { Commonwealth } \\
\text { Cities } \\
\end{array}$ & $\begin{array}{l}\text { PC } 3(23.2 \%) \\
\text { Market } \\
\text { Communism } \\
\text { Cities } \\
\end{array}$ \\
\hline $.80-.89$ & $\begin{array}{l}\text { Singapore } .808 \\
\text { Sydney } .806\end{array}$ & $\begin{array}{l}\text { Brisbane } .892 \\
\text { Wellington } .865 \\
\text { Auckland } .84 \\
\text { Adelaide } .818 \\
\end{array}$ & $\begin{array}{l}\text { Shanghai .853 } \\
\text { Guangzhou } .811\end{array}$ \\
\hline $.70-.79$ & $\begin{array}{l}\text { Manila } .784 \\
\text { Taipei } .722 \\
\text { Jakarta } .712 \\
\end{array}$ & Vancouver .788 & Ho Chi Minh .752 \\
\hline $.60-.69$ & $\begin{array}{l}\text { Beijing .695 } \\
\text { Hong Kong .678 } \\
\text { Bangkok .671 } \\
\text { Melbourne .602 } \\
\end{array}$ & & $\begin{array}{l}\text { Hanoi .658 } \\
\text { Kuala Lumpur } \\
.627\end{array}$ \\
\hline $.50-.59$ & \begin{tabular}{|l} 
Seoul .575 \\
Santiago .506 \\
\end{tabular} & Melbourne .584 & \begin{tabular}{|l} 
Bangkok .576 \\
Seoul .527 \\
\end{tabular} \\
\hline $.40-.49$ & Tokyo .482 & \begin{tabular}{|l} 
Osaka .488 \\
Tijuana .485 \\
Santiago .473 \\
Sydney .416 \\
\end{tabular} & $\begin{array}{l}\text { Lima } .482 \\
\text { Taipei } .465 \\
\text { Beijing } .424\end{array}$ \\
\hline
\end{tabular}

\begin{tabular}{|l|l|l|}
\hline Loading level & $\begin{array}{l}\text { PC 4 }(\mathbf{9 . 7 \%}) \\
\text { Pacific US } \\
\text { Cities }\end{array}$ & $\begin{array}{l}\text { PC 5 (10.8\% })^{4} \\
\text { Global City }\end{array}$ \\
\hline $.80-.89$ & $\begin{array}{l}\text { Los Angeles .65 } \\
\text { Seattle .602 }\end{array}$ & Tokyo .759 \\
\hline $.70-.79$ & & Lima .53 \\
\hline $.60-.69$ & & $\begin{array}{l}\text { Osaka } .486 \\
\text { Santiago } .496\end{array}$ \\
\hline $.50-.59$ & &
\end{tabular}


Table 3 Component scores of global service firms (only scores above +1 and below -1 are shown)(for names of firms, see Appendix A)

\begin{tabular}{|c|c|c|c|c|c|}
\hline & PC 1 & PC 2 & PC 3 & PC 4 & PC 5 \\
\hline Accountancy & & $\begin{array}{l}\text { KP } 2.74 \\
\text { CL } 2.38 \\
\text { PW } 1.93 \\
\text { EY } 1.59 \\
\text { AA } 1.24\end{array}$ & PW 1.05 & $\begin{array}{l}\text { KP } 1.35 \\
\text { EY } 1.31 \\
\text { CL } 1.0\end{array}$ & $\begin{array}{l}\text { EY } 1.9 \\
\text { AA } 1.22 \\
\text { CL } 1.07\end{array}$ \\
\hline Advertising & $\begin{array}{l}\text { PU } 1.34 \\
\text { DE } 1.21\end{array}$ & $\begin{array}{l}\text { AM } 2.67 \\
\text { PU } 1.35 \\
\text { TM } 1.3 \\
\end{array}$ & $\begin{array}{l}\text { DE } 2.99 \\
\text { TH } 1.41\end{array}$ & & \\
\hline $\begin{array}{l}\text { Banking and } \\
\text { Finance }\end{array}$ & $\begin{array}{l}\text { BT } 2.0 \\
\text { BA } 1.95 \\
\text { MO } 1.7 \\
\text { NW } 1.22 \\
\end{array}$ & & \begin{tabular}{|l} 
ST 2.95 \\
HS 2.27 \\
PA 1.3 \\
AB 1.09 \\
\end{tabular} & MO 1.07 & $\begin{array}{l}\text { BB } 2.23 \\
\text { HS } 1.52 \\
\text { CS } 1.36 \\
\text { PA } 1.17 \\
\end{array}$ \\
\hline Law & BM 3.46 & & & $\begin{array}{l}\text { GJ } 3.26 \\
\text { SK } 1.53 \\
\text { CO } 1.43 \\
\text { WE } 1.09 \\
\text { LL } 1.08 \\
\end{array}$ & \\
\hline Accountancy & & & & & \\
\hline Advertising & TM -1.48 & & YR -1.33 & $\begin{array}{l}\text { OM - } 1.08 \\
\text { PU -1.12 } \\
\text { AM - } 1.82 \\
\end{array}$ & $\begin{array}{l}\text { AM - } 1.38 \\
\text { PU -2.46 } \\
\text { DE -3.15 } \\
\end{array}$ \\
\hline $\begin{array}{l}\text { Banking and } \\
\text { Finance }\end{array}$ & & $\begin{array}{l}\text { HS - } 1.07 \\
\text { PA - } 1.18 \\
\text { ST }-1.35 \\
\end{array}$ & & $\begin{array}{l}\text { BT }-1.29 \\
\text { BB }-2.02\end{array}$ & NW -1.13 \\
\hline Law & $\begin{array}{l}\text { GJ }-1.03 \\
\text { SQ }-1.05 \\
\text { MC }-1.05 \\
\text { HH }-1.07 \\
\text { DW }-1.18\end{array}$ & & $\begin{array}{l}\text { SK -1.04 } \\
\text { BM -1.57 }\end{array}$ & & \\
\hline
\end{tabular}




\section{Figure 1 Components as city groupings}

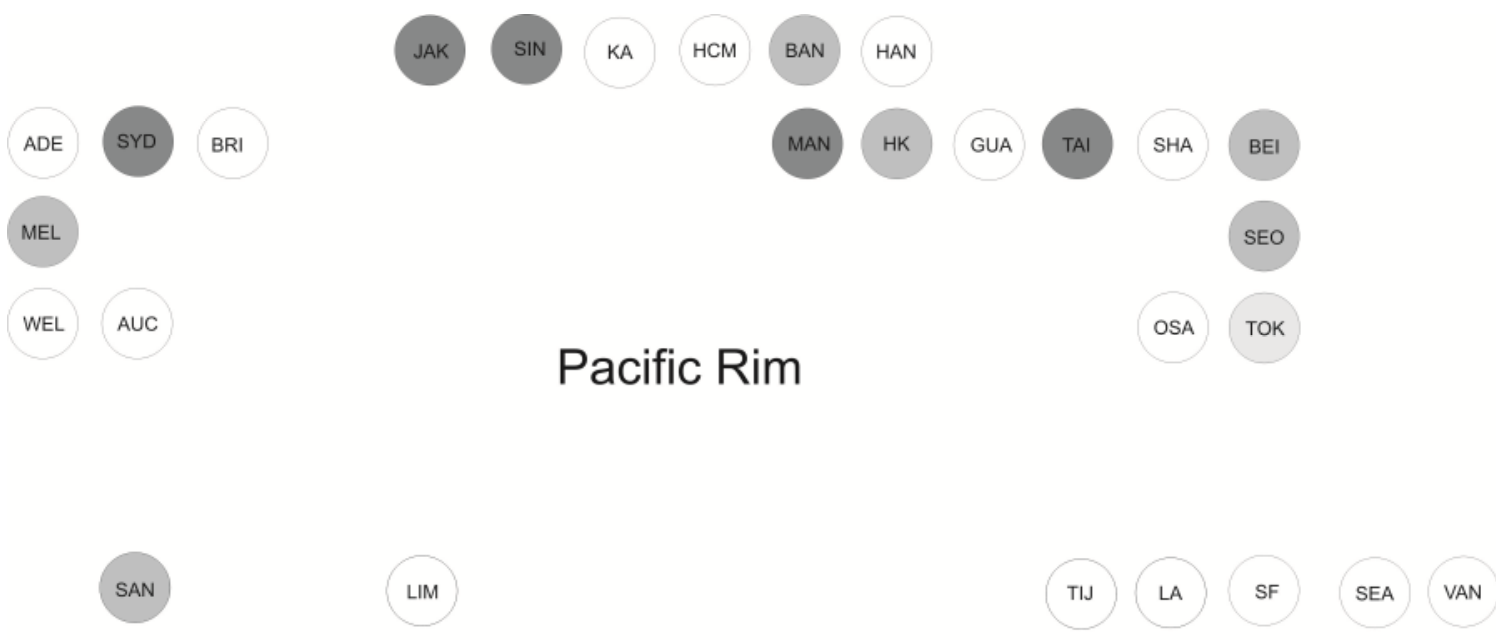

PC 1: Western RimCities

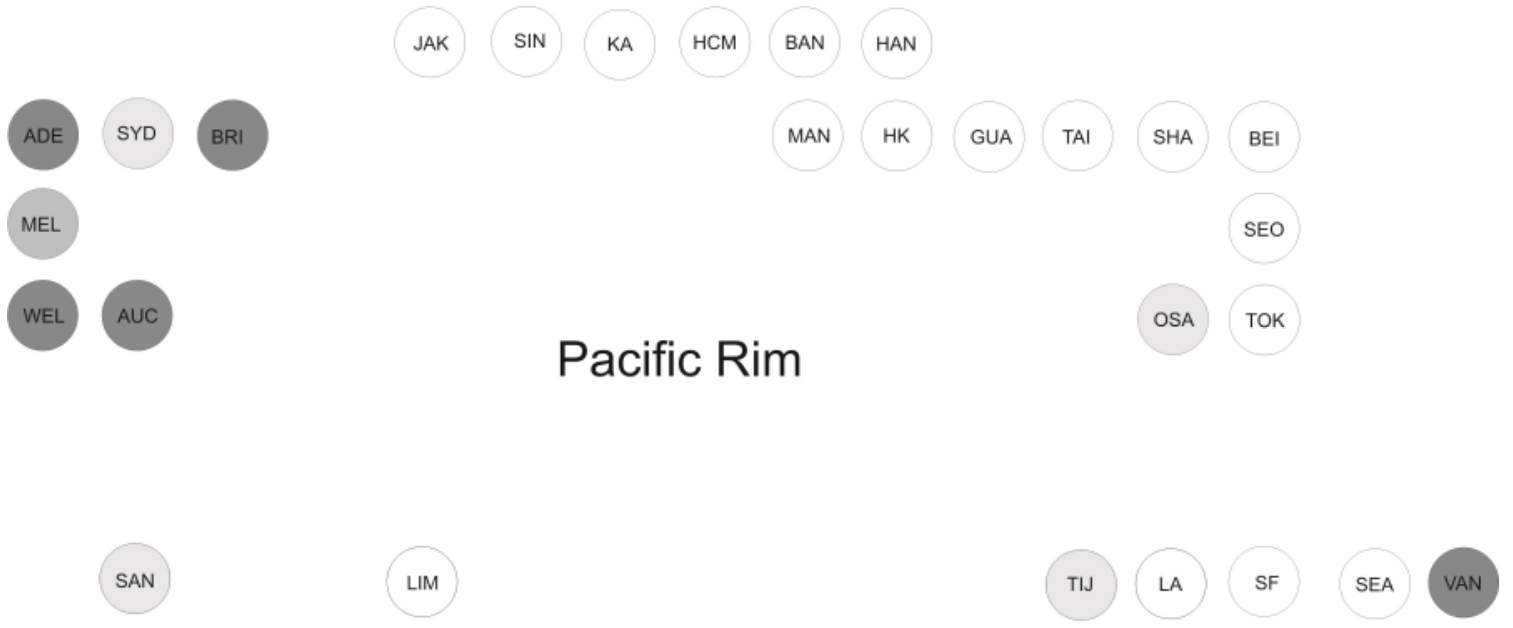

PC 2: Old Commonwealth Cities 


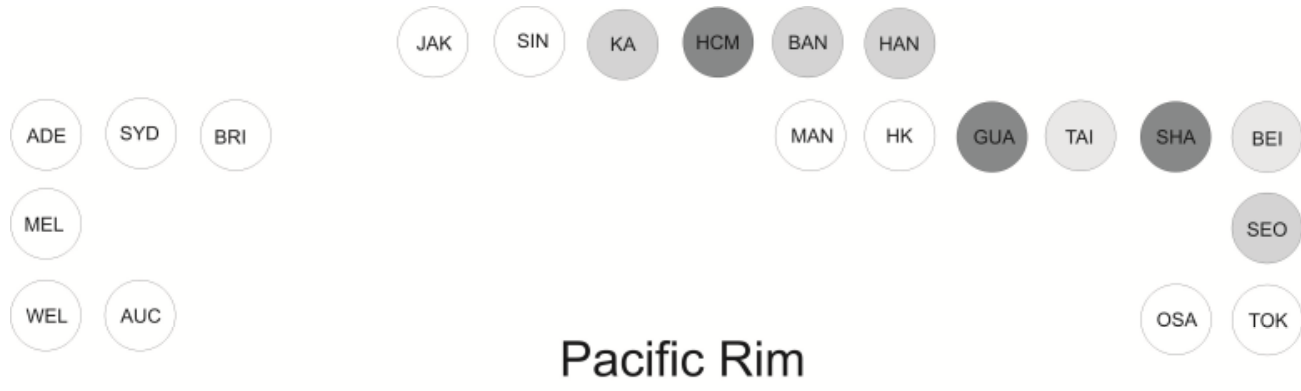

PC 3: Market Communism Cities

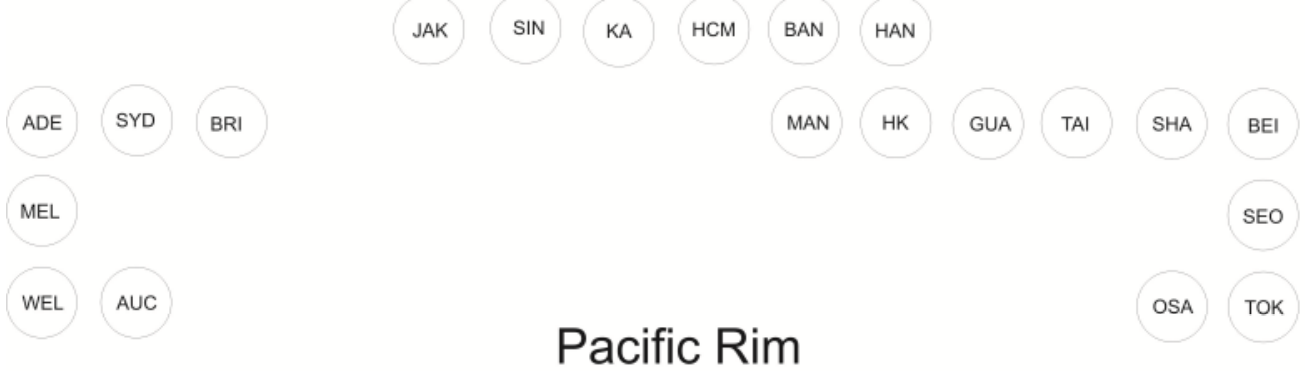

PC 4: Pacific US Cities 

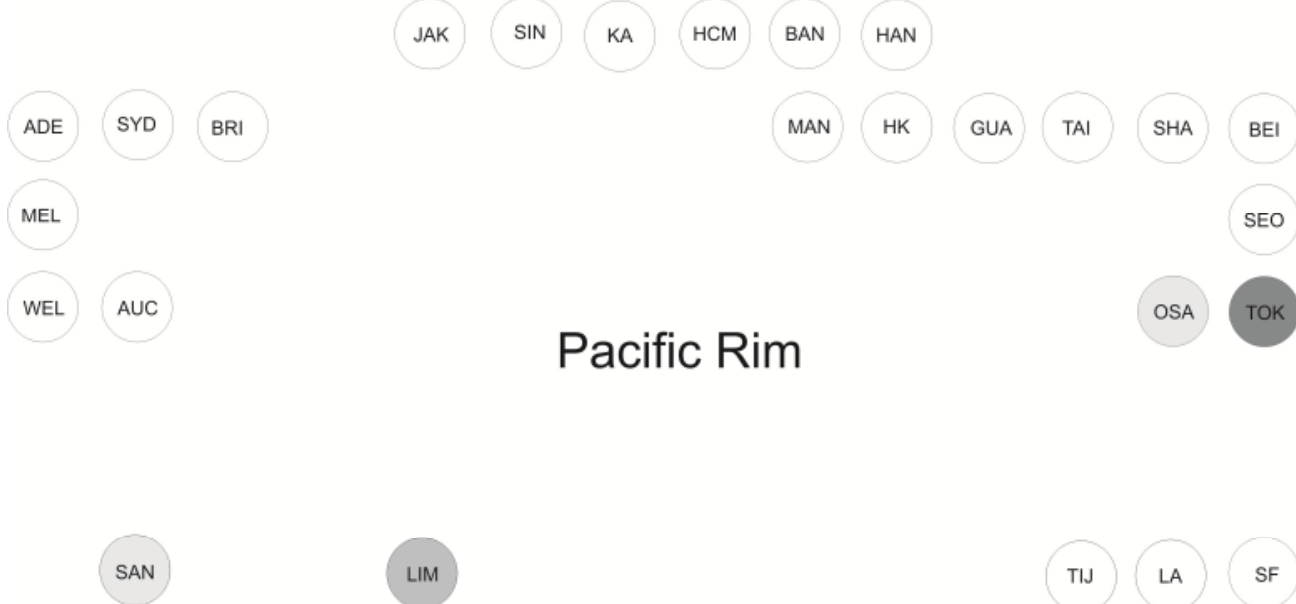

(TIJ LA SF SEA VAN

PC 5: Global City

Note: Full names of the cities are in Table 1. 